\title{
Pulmonary mechanical function and diffusion capacity after deep saturation dives
}

\author{
E Thorsen, K Segadal, E Myrseth, A Påsche, A Gulsvik
}

\begin{abstract}
To assess the effects of deep saturation dives on pulmonary function, static and dynamic lung volumes, transfer factor for carbon monoxide $\left(\mathrm{Tl}_{\mathrm{co}}\right)$, delta- $\mathrm{N}_{2}$, and closing volume $(\mathrm{CV})$ were measured before and after eight saturation dives to pressures of 3.1-4.6 MPa. The atmospheres were helium-oxygen mixtures with partial pressures of oxygen of $40-60 \mathrm{kPa}$. The durations of the dives were 14-30 days. Mean rate of decompression was $10.5-13.5 \mathrm{kPa} / \mathrm{hour}$. A total of $\mathbf{4 3}$ divers were examined, six of whom took part in two dives, the others in one only. Dynamic lung volumes did not change significantly but total lung capacity (TLC) increased significantly by $4 \cdot 3 \%$ and residual volume (RV) by $14.8 \%(p<0.05)$. CV was increased by $16.7 \%(\mathrm{p}<0.01)$. The $\mathrm{Tl}_{\mathrm{co}}$ was reduced from $13.0 \pm 1.6$ to $11.8 \pm 1.7 \mathrm{mmol} / \mathrm{min} /$ $\mathrm{kPa}(\mathrm{p}<0.01)$ when corrected to a haemoglobin concentration of $146 \mathrm{~g} / 1$. Effective alveolar volume was unchanged. The increase in $\mathrm{TLC}$ and decrease in $\mathrm{Tl}_{\text {co }}$ were correlated $(r=-0.574, p<0.02)$. A control examination of 38 of the divers four to six weeks after the dives showed a partial normalisation of the changes. The increase in TLC, RV, and $C V$, and the decrease in $\mathrm{Tl}_{\text {co, }}$ could be explained by a loss of pulmonary elastic tissue caused by inflammatory reactions induced by oxygen toxicity or venous gas emboli.
\end{abstract}

During deep saturation dives, the lungs are exposed to an artificial atmosphere with high density and usually a raised partial pressure of oxygen of 40-60 $\mathrm{kPa}$ during decompression to facilitate inert gas elimination. The increased work of breathing imposed by the increased density of the breathing gas is depth related ${ }^{1}$ and the ventilatory capacity will eventually become a limiting factor for physical work

Norwegian Underwater Technology Centre A/S (NUTEC), Gravdalsveien 255, 5034 Ytre Laksevåg, and Department of Thoracic Medicine, University of Bergen, Norway

E Thorsen, K Segadal, E Myrseth, A Påsche, A Gulsvik capacity. During long exposures, toxic effects of oxygen in this concentration range cannot be excluded and during decompression the venous gaș microemboli filtered in the pulmonary circulation may also induce inflammatory reactions in the lungs and gas exchange abnormalities. ${ }^{23}$

An increase in vital capacity has in some cases been? reported after saturation dives, attributed to a train $\vec{b}$ ing effect of respiratory muscles. ${ }^{4-6}$ Hyacinthe et al $\frac{\delta}{2}$. and Cotes $e t a l^{6}$ have also shown reduced transfer factor for carbon monoxide $\left(\mathrm{Tl}_{\mathrm{co}}\right)$ immediately aftef two deep dives to a pressure equal to $3.1 \mathrm{MPa}$. This could be an effect of oxygen toxicity but effects of microembolisation cannot be excluded. Probably alf decompressions from those depths will produc venous gas emboli filtered in the pulmonary circula tion but not necessarily associated with clinica decompression sickness. ${ }^{8}$

The possibility of long term effects on pulmonary function of professional diving is still controversialThe cross sectional studies of divers' lung function by Watt,' Davey et al, ${ }^{10}$ and Crosbie et al ${ }^{11}$ show larger than predicted vital capacities of divers bu@ lower than predicted maximal flow rates at low lung volumes. This may indicate an airflow limitation buE it is not known whether it is an adaptive response tón diving or a progressive deterioration of lung func $-\frac{0}{3}$ tion.

We have measured pulmonary function before and after eight deep saturation dives in Norway durins the period 1983-6 to evaluate the magnitude and functional significance of changes in pulmonaryo function.

\section{Methods}

THE DIVES

Eight dives numbered 1 to 8 (table 1 ) in the dept range equivalent to a pressure of $3 \cdot 1-4.6 \mathrm{MPa}(300$ 450 metres of sea water-msw) ${ }^{\star}$ were studied. Tw\& were open sea dives (dives 5 and 6 ) whereas the otherso were simulated in the NUTEC onshore hyperbarie chamber complex. Welding trials were performed i⿱ dives 2 and 8 . Equipment and operational procedure $\mathbb{8}$ were tested both in the dry and wet. The durations of the dives were 14-30 days. The mean rate of decom pression was $10.5-13.5 \mathrm{kPa} / \mathrm{h}$. The atmosphere was

${ }^{\star} 1 \mathrm{MPa}=100 \mathrm{msw}=10 \mathrm{bar}, 100 \mathrm{kPa}=10 \mathrm{msw}=1 \mathrm{bar}$. 
helium-oxygen mixtures with partial pressures of oxygen of $40-60 \mathrm{kPa}$. Table 1 gives the characteristics of each dive. The number of divers in each saturation dive was four to nine, giving a total of 49 man dives. The diving procedures and the protocol for medical and physiological monitoring of the divers were approved by the Regional Ethical Review Committee (dives 1-5) and the ethical committee of the Norwegian Research Council for Science and the Humanities (dives 6-8).

\section{THE DIVERS}

Forty three professional divers participated in the dives. Their average age was $30 \cdot 3$ years (range 2339), weight 78.3 kg (range 67-91), and height $180 \cdot 2$ cm (range 168-193). Ten were current smokers, four ex-smokers, and 29 non-smokers. Their experience as saturation divers was on average 5.8 years (range 1-9) and their total number of days in saturation on average 270 days (range 5-600). On the first examination before the dives, they had all passed the annual medical examination required by the Norwegian Directorate of Public Health for offshore diving. The time since their last routine saturation dive (less than $1.9 \mathrm{MPa}$ ) was at least four weeks. Six divers participated in two of the deep saturation dives described here and the time between their deep dives was from five months to two years.

\section{PROTOCOI}

The divers were first examined four to six weeks before the dives (predive) and re-examined one to three days (first postdive) and four to six weeks (second postdive) after the dives. Three divers were examined at other institutes predive and their results are not included in this study. A second postdive examination was not done after dives 1 and 5 . From 1983 to 1984 (dives 6-8) the examinations included clinical examination, dynamic lung volumes, and diffusion capacity. Later (dives 1-5), static lung volumes and distribution of ventilation were also included. Chest radiographs were taken in connection with dives 1 and 4 only.

\section{Table 1 Characteristics of the dives}

\begin{tabular}{lllll}
\hline Dive & $\begin{array}{l}\text { No of } \\
\text { divers }\end{array}$ & $\begin{array}{l}\text { Pressure } \\
(M P a)\end{array}$ & $\begin{array}{l}\text { Duration } \\
\text { (days) }\end{array}$ & $\begin{array}{l}\text { Partial pressure } \\
\text { of oxygen } \dagger \\
\text { (kPa) }\end{array}$ \\
\hline 1 & 6 & $3 \cdot 7$ & $2+3+13$ & $40-50$ \\
2 & 6 & $3 \cdot 7$ & $2+10+13$ & $40-50$ \\
3 & 6 & $3 \cdot 7$ & $2+12+13$ & $40-50$ \\
4 & 6 & $4 \cdot 6$ & $2+10+18$ & $40-50$ \\
5 & 4 & $3 \cdot 1$ & $1+3+10$ & $40-50$ \\
6 & 9 & $3 \cdot 1$ & $1+9+9$ & $40-60$ \\
7 & 6 & $3 \cdot 6$ & $2+11+11$ & $40-60$ \\
8 & 6 & $3 \cdot 6$ & $2+6+11$ & $40-50$ \\
\hline
\end{tabular}

$\star$ Compression time + bottom time + decompression time.

+Bottom phase and decompression phase.

\section{ASSESSMENT OF PULMONARY FUNCTION}

\section{Static lung volumes}

The multibreath nitrogen washout technique was used to measure functional residual capacity (FRC). Combined with the measurements of expiratory reserve volume (ERV) and inspiratory vital capacity (IVC), total lung capacity (TLC) and residual volume $(R V)$ were calculated.

\section{Dynamic lung volumes}

A minimum of three satisfactory forced vital capacity manoeuvres were performed. ${ }^{12}$ The forced expiratory vital capacity (FEVC), forced expired volume in one second $\left(\mathrm{FEV}_{1}\right)$, and peak expiratory flow rate (PEF) were taken as the highest readings obtained. The forced mean mid-expiratory flow rate $\left(\mathrm{FEF}_{25-75^{\prime \prime}}\right)$ and forced expiratory flow rates at $50 \%$ and $75^{\circ} \%$ of FEVC expired $\left(\mathrm{FEF}_{50^{\prime \prime},}, \mathrm{FEF}_{75^{\circ},}\right)$ were taken as the highest readings from flow volume curves not differing by more than $5 \%$ from the highest FEVC. The forced inspiratory vital capacity (FIVC), forced inspired volume in one second $\left(\right.$ FIV $\left._{1}\right)$, forced inspiratory flow rate at $50 \%$ of FIVC $\left(\mathrm{FIF}_{50}{ }^{\prime . .}\right)$, and peak inspiratory flow rate (PIF) were taken as the highest readings obtained. Maximum voluntary ventilation (MVV) was measured as the highest ventilation sustained for 12 seconds.

\section{Diffusion capacity}

$\mathrm{Tl}_{\mathrm{CO}}$ was measured by the single breath holding method. ${ }^{12}$ Effective alveolar volume $\left(V_{A}\right)$ was then measured simultaneously by helium dilution and transfer per unit effective alveolar volume $\left(\mathrm{K}_{\mathrm{co}}\right)$ was calculated. $\mathrm{Tl}_{\mathrm{CO}}$ was corrected to a haemoglobin concentration of $146 \mathrm{~g} / \mathrm{l}$.

\section{Distribution of ventilation}

During the multibreath nitrogen washout test for measuring FRC, the nitrogen washout time (NWT) (time to bring expired $\mathrm{N}_{2}$ concentration below $2 \%$ ) and the lung clearance index (LCI) (volume ventilated to bring expired $\mathrm{N}_{2}$ concentration below $2 \%$ relative to FRC) were measured. The slope of phase 3 of the single breath $\mathrm{O}_{2}$ test-delta $\mathrm{N}_{2}$-was also measured along with closing volume $(\mathrm{CV})$ at the point of inflection between phases 3 and 4 . Closing capacity (CC) was calculated as the sum of RV and CV.

The predive and postdive examinations were performed with the same equipment and technicians on each occasion at least two hours after breakfast without tea or coffee and with no smoking in the last two hours before the examination. Volume and test gas calibrations were done before each test and the results were corrected to the BTPS condition.

\section{STATISTICS}

For comparison of results between predive and 
postdive examinations paired Students $t$ test was applied. Least squares linear regression analysis was done for correlation analysis. Differences between examinations were calculated as difference from the mean. All data are expressed as mean \pm 1 SD. A p value less than 0.05 was considered significant. ${ }^{13}$

\section{Results}

On the predive examinations none of the divers reported pulmonary symptoms and the clinical examinations of the heart and lungs were considered normal. Immediately after the dives retrosternal discomfort was reported by 20 divers, including nine with a non-productive cough provoked by deep inspirations. Otherwise non-specific symptoms of weakness, general fatigue, and insomnia were reported. Clinical examinations were still normal and in the two dives where chest radiographs were taken they were also normal. All symptoms had gradually disappeared during the first two weeks after the dives.

\section{STATIC LUNG VOLUMES}

In 24 divers diving to 3.7 and $4.6 \mathrm{MPa}$ there was a significant increase in TLC of $4.3 \%$, FRC of $11.6 \%$, and $\mathrm{RV}$ of $14.8 \%$ from the predive to first postdive examination. The IVC and ERV were unchanged (table 2). On the second postdive examination the TLC and its subdivisions were partially normalised (fig 1).

\section{DYNAMIC LUNG VOLUMES}

There were no changes from the predive through the first and second postdive examinations when all dives

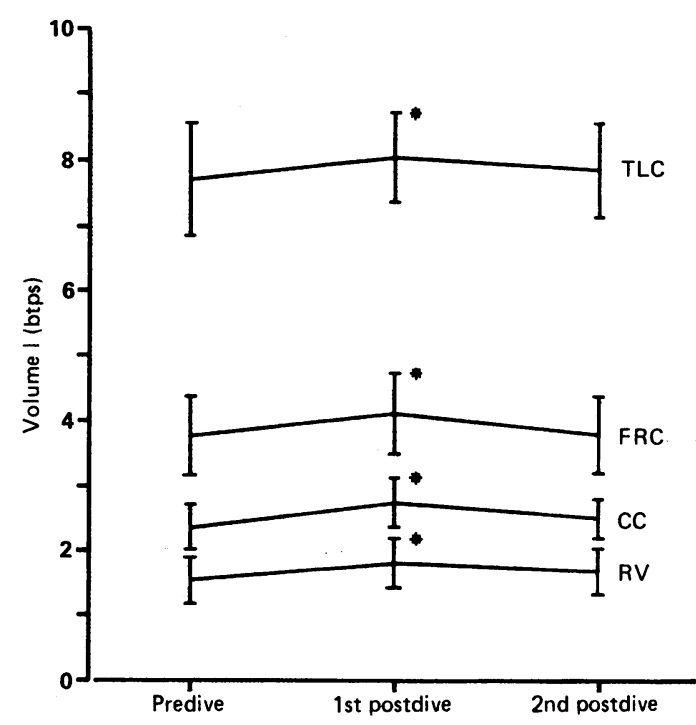

Fig 1 Static lung volumes on predive and postdive examinations. * Significantly different from predive.

were pooled (table 2). In dives 2, 3, and 4 FEVC increased significantly from the predive to first postdive examination by $3.8 \%, 5.6 \%$, and $8.1 \% \%$ respectively, whereas $\mathrm{FEV}_{1}$ and flow rates at other $\stackrel{\mathrm{D}}{\mathbb{D}}$ lung volumes were unchanged (fig 2 ). As shown in $\overrightarrow{\vec{P}}$ figure 3 , the outline of the flow volume curves did not 3 differ, only their positions related to absolute lung volume, which means that at the same absolute lungo volume, flow rate was lower postdive. The change in FEVC (all dives) did not correlate with diver's age $\stackrel{\mathbb{D}}{7}$

Table 2 Results of selected pulmonary function tests. $n$ refers to number of examinations

\begin{tabular}{|c|c|c|c|}
\hline & Predive & $\begin{array}{l}\text { First } \\
\text { postdive }\end{array}$ & $\begin{array}{l}\text { Second } \\
\text { postdive }\end{array}$ \\
\hline & $(n=46)$ & $(n=46)$ & $(n=38)$ \\
\hline 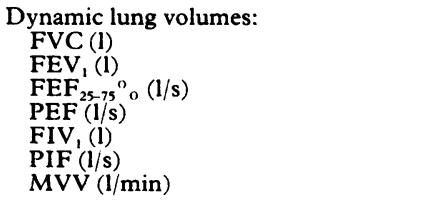 & $\begin{array}{l}6 \cdot 10 \pm 0.68 \\
4 \cdot 81 \pm 0 \cdot 55 \\
4 \cdot 57 \pm 1 \cdot 13 \\
11 \cdot 95 \pm 1 \cdot 43 \\
5 \cdot 52 \pm 0 \cdot 85 \\
8 \cdot 81 \pm 2 \cdot 27 \\
174 \pm 19\end{array}$ & $\begin{array}{l}6 \cdot 17 \pm 0 \cdot 64 \\
4 \cdot 78 \pm 0 \cdot 56 \\
4 \cdot 41 \pm 1 \cdot 15 \\
11 \cdot 71 \pm 1 \cdot 48 \\
5 \cdot 25 \pm 0 \cdot 78 \\
8 \cdot 40 \pm 2 \cdot 20 \\
182 \pm 24\end{array}$ & $\begin{array}{l}6 \cdot 16 \pm 0 \cdot 60 \\
4 \cdot 69 \pm 0 \cdot 55 \\
4 \cdot 54 \pm 1 \cdot 20 \\
11 \cdot 77 \pm 1 \cdot 37 \\
5 \cdot 31 \pm 0 \cdot 80 \\
8 \cdot 63 \pm 2 \cdot 34 \\
171 \pm 24\end{array}$ \\
\hline $\begin{array}{l}\text { Static lung volumes: } \\
\text { TLC (1) } \\
\text { FRC (1) } \\
\text { RV }(1) \\
\text { CV }\left({ }^{\circ}, \mathrm{VC}\right) \\
\text { CC (1) }\end{array}$ & $\begin{array}{l}n=24 \\
7 \cdot 70 \pm 0.85 \\
3 \cdot 77 \pm 0.74 \\
1.56 \pm 0.36 \\
11 \cdot 0 \pm 1 \cdot 6 \\
2 \cdot 35 \pm 0.41\end{array}$ & $\begin{array}{l}n=24 \\
8 \cdot 04 \pm 0 \cdot 67^{\star} \\
4 \cdot 11 \pm 0 \cdot 61^{\star} \\
1 \cdot 81 \pm 0 \cdot 37^{\star} \\
13 \cdot 0 \pm 1 \cdot 8^{\star} \\
2 \cdot 74 \pm 0 \cdot 37^{\star}\end{array}$ & $\begin{array}{l}n=24 \\
7 \cdot 86 \pm 0 \cdot 70 \\
3 \cdot 79 \pm 0 \cdot 68 \\
1 \cdot 69 \pm 0 \cdot 34 \\
11 \cdot 2 \pm 2 \cdot 1 \\
2 \cdot 50 \pm 0 \cdot 40\end{array}$ \\
\hline $\begin{array}{l}\text { Diffusion capacity: } \\
\mathrm{Tl}_{\mathrm{co}}(\mathrm{mmol} / \mathrm{min} / \mathrm{kPa}) \\
\mathrm{K}_{\mathrm{co}}(\mathrm{mmol} / \mathrm{min} / \mathrm{kPa} / \mathrm{l}) \\
\mathrm{V}_{\mathrm{A}}(\mathrm{l}) \\
\mathrm{Hb}(\mathrm{g} / \mathrm{l}) \\
\text { Packed cell volume (volume fraction) }\end{array}$ & $\begin{array}{l}n=46 \\
13 \cdot 00 \pm 1 \cdot 62 \\
1 \cdot 60 \pm 0 \cdot 20 \\
8 \cdot 13 \pm 0 \cdot 80 \\
147 \pm 11 \\
0 \cdot 44 \pm 0.02\end{array}$ & $\begin{array}{l}\mathrm{n}=46 \\
11.82 \pm 1.66^{\star \star} \\
1.44 \pm 0.17^{\star} \\
8.20 \pm 0.73 \\
138 \pm 15 \\
0.42 \pm 0.02\end{array}$ & $\begin{array}{l}n=38 \\
12.62 \pm 1.66 \\
1.53 \pm 0.21 \\
8.24 \pm 0.84 \\
139 \pm 13 \\
0.42 \pm 0.03\end{array}$ \\
\hline
\end{tabular}



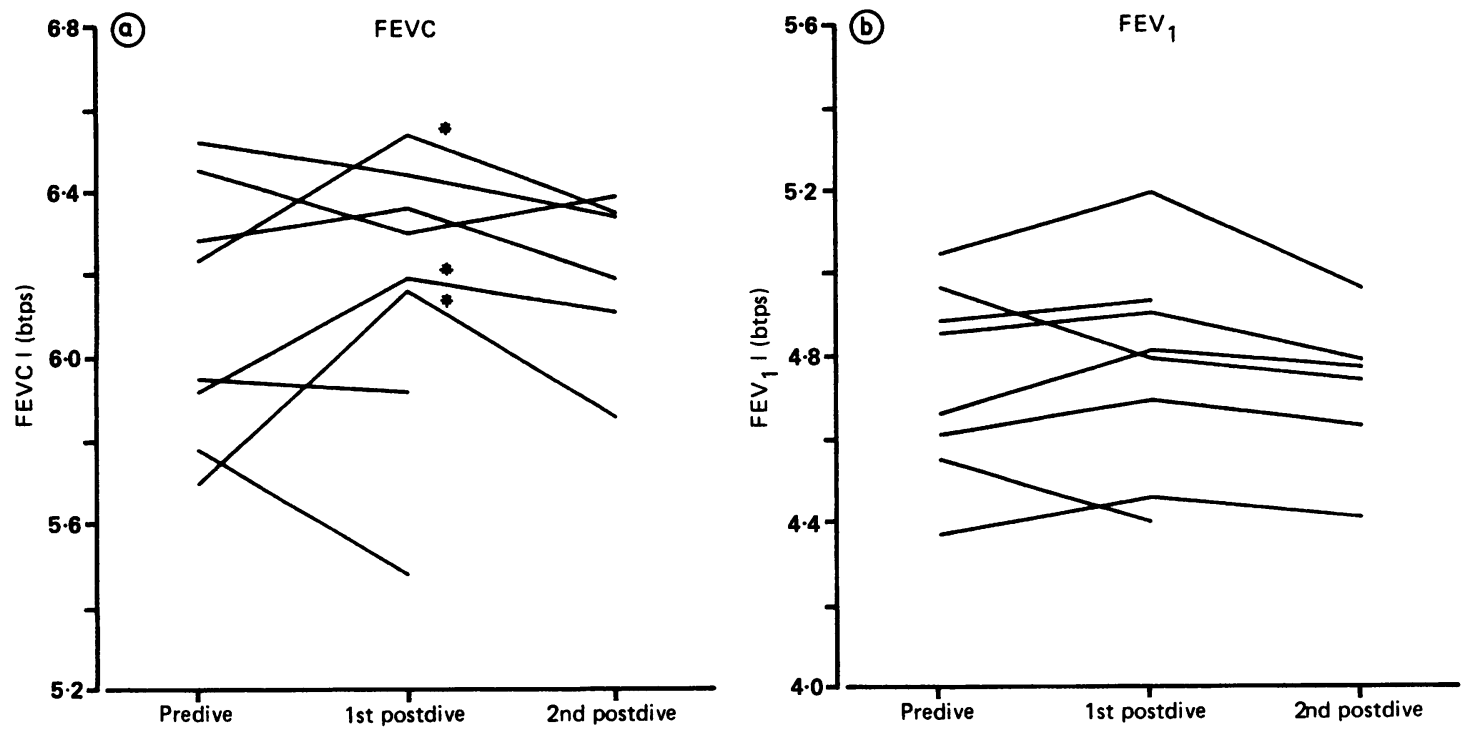

Fig 2 FEVC and FEV, predive and postdive. Means for each dive, Nos 1-8, are plotted. * Significantly different from predive $(p<0.05)$.

$(r=0.139)$ or depth $(r=0.196)$ or rate of decompression $(r=0.224)$ but correlated positively with duration of the dives $(r=0.359, p<0.02)$. The dives where welding was performed showed no specific trends compared with the other dives.

\section{DISTRIBUTION OF VENTILATION}

There were no changes in the distribution indices delta- $\mathrm{N}_{2}, \mathrm{LCI}$, or nitrogen washout time. The clos-

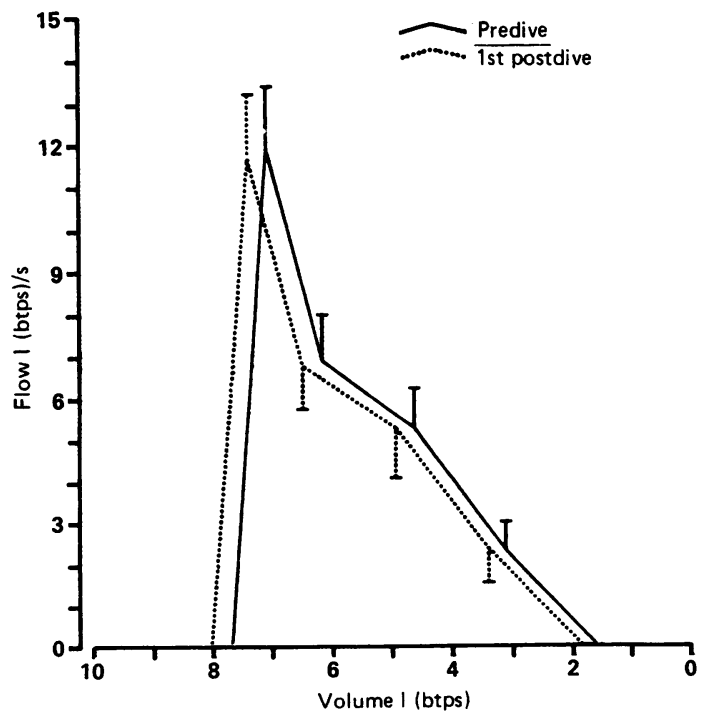

Fig 3 Flow volume loops at predive and first postdive examinations related to absolute lung volume $(n=24)$. $1 S D$ is shown in only one direction. ing volume was significantly increased from $11.0 \pm$ 1.6 to $13.0 \pm 1.8 \%$ of VC $(p<0.05)$. Since both RV and $\mathrm{CV}$ were increased, closing capacity was also increased (table 2).

\section{TRANSFER FACTOR FOR CARBON MONOXIDE}

$\mathrm{Tl}_{\text {co }}$ was significantly reduced by $9.5 \%$ immediately after the dives. $K_{c o}$ was reduced by the same magnitude $(9 \cdot 0 \%)$. Figure 4 shows the results of $\mathrm{Tl}_{\mathrm{CO}}$

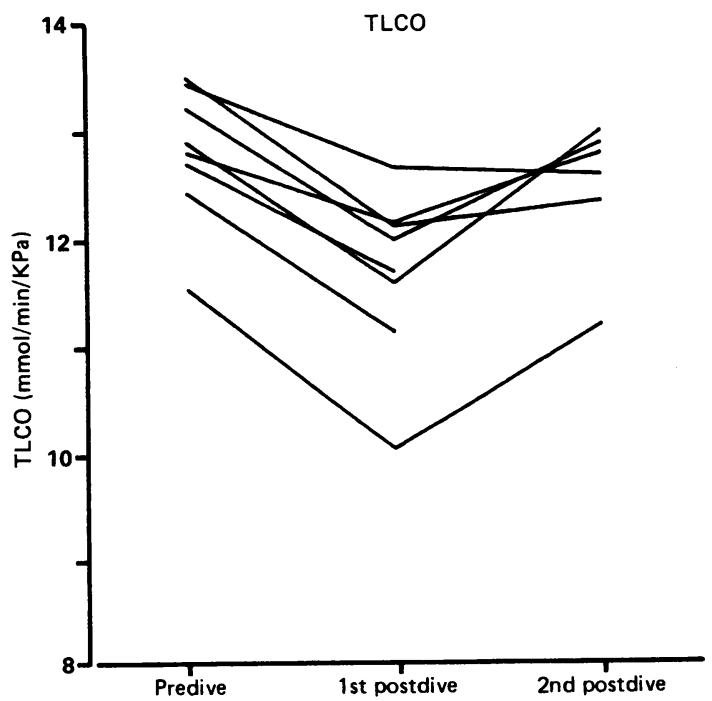

Fig $4 \mathrm{Tl}_{\text {co }}$ predive and postdive. Means for each dive, Nos 1-8, are plotted. All means at first postdive examination differ significantly from predive $(p<0.05)$. 


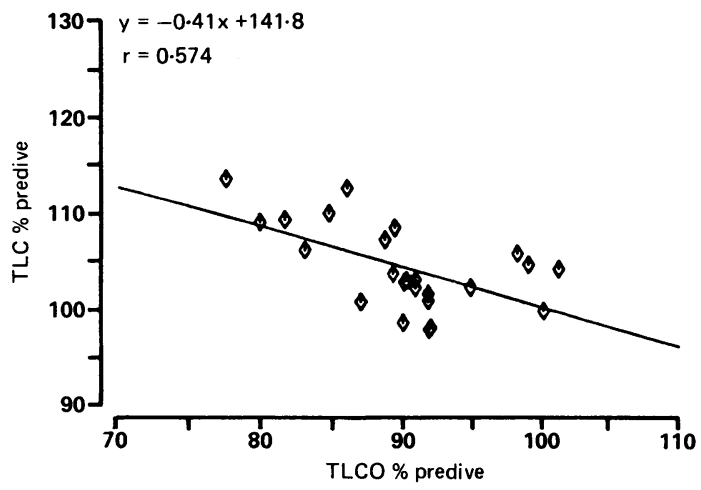

Fig 5 Correlation plot between change in $T L C$ and $T l_{c o}$ from predive to first postdive examination.

in each dive. The reduction in $\mathrm{Tl}_{\mathrm{CO}}$ did not correlate with duration of the dive $(r=0 \cdot 123)$, diver's age $(r=-0.060)$, or depth $(r=0.099)$ but there was a significant negative correlation between change in TLC and change in $\mathrm{Tl}_{\mathrm{CO}}(\mathrm{r}=-0.574, \mathrm{p}<0.02)$ (fig 5). $\mathrm{Tl}_{\mathrm{Co}}$ was still reduced on the second postdive examination four to six weeks after the dives (dives 1 and 5 not examined), the reduction being $5.6 \%$ (NS). The reduction in $\mathrm{Tl}_{\mathrm{CO}}$ of divers decompressed at a partial pressure of oxygen of $50 \mathrm{kPa}$ and $60 \mathrm{kPa}$ were $9 \cdot 7 \%$ and $9 \cdot 1 \%$ respectively (NS).

\section{Discussion}

Twenty of the 43 divers reported chest symptoms persisting for up to two weeks after the dives. The symptoms were consistent with a tracheobronchitis that may be induced by raised partial pressure of oxygen. A reduction in VC, which is a characteristic finding in oxygen toxicity, was not shown. The results of the assessment of static and dynamic lung volumes indicate an expansion of the lungs. Some reports indicate an increase in VC immediately after deep dives ${ }^{56}$ but this was seen in only three of our dives. The TLC and VC may be increased by a training effect because of raised breathing resistance. The results of training of respiratory muscles by loaded breathing ${ }^{14}$ and swimming ${ }^{15}$ have shown an increase in FRC, TLC, and VC but unchanged RV. An increase in residual volume has also been shown after a saturation dive to $1.86 \mathrm{MPa}$. ${ }^{4}$ The significant correlation between duration of the dive and increase in FEVC could reflect a training effect. There was no increase in PEF, MVV, or maximal inspiratory flow rates, which are effort dependent, to support this. Maximal respiratory pressures were not measured in this study but Cotes et al did not find changes in maximal respiratory pressures after the dive to $3 \cdot 1$ $\mathrm{MPa}$ where there was an increase in FEVC of $6.8 \%{ }^{6}$

The capillary endothelial cells are probably the most vulnerable structure to hyperoxic injury with disruption of the endothelial lining and occlusion of capillaries and small arterioles. ${ }^{16}$ Venous gas embol- $\overrightarrow{\vec{\rho}}$ isation will also result in a microvascular injury with $\overrightarrow{0}$ occlusion of capillaries and increased permeability of $\frac{}{O}$ the endothelium. ${ }^{1718}$ Reduced static lung volumes, $\overline{\bar{c}}$ which are characteristic of oxygen toxicity, will not $\mathbb{R}$ be seen unless the lymphatic drainage capacity of the lungs is overloaded, forming oedema. Existing ${ }^{\text {s }}$ oxygen tolerance tables indicate an oxygen concen- $\vec{O}$ tration of $50 \mathrm{kPa}$ as being harmless, ${ }^{19}$ but there exists $\overrightarrow{\overrightarrow{.}}$ no experience to support this when exposure time is ${ }_{\sigma}^{\omega}$ more than two weeks. These tables are based on $\bar{\phi}$ changes in vital capacity as the measure of oxygen $\frac{\mathbb{}}{3}$ toxicity but other lung function variables such as the $\mathrm{Tl}_{\text {co }}$ would probably detect changes at an earlier stage.

The inflammatory processes associated with $\stackrel{\vec{N}}{0}$ oxygen toxicity and gas embolism injury may destroy 윽 pulmonary elastic tissue through the mechanisms of oxygen radicals. In a study by Riley et al in mice $?$ exposed to hyperoxia a degradation of collagen was shown with a reduced pulmonary recoil pressure and $\vec{\bullet}$ histopathological evidence of an emphysematous $\Theta$ lesion eight weeks after exposure. ${ }^{20}$ Oxygen radicals ${ }^{\circ}$ are also involved in the process of injury after air embolisation. ${ }^{21} 22$ The pattern of changes in static lung volumes in our study may be explained by that mechanism resulting in a loss of pulmonary elastic tissue. The increase in closing capacity and reduction of $\mathrm{Tl}_{\mathrm{CO}}$ is also consistent with this.

The characteristics of divers' lung function des- $\exists$ cribed by Crosbie et al indicates a slight bronchial obstruction in divers. ${ }^{11}$ It is not known whether it is a? real obstruction or a result of the divers' significantly $\bar{\partial}$ higher than predicted lung volumes. Our study 3 indicates that a slight obstruction might be induced by the dives when looking at both the increase in RV and TLC and maximum flow rates at absolute lungo volumes. At a given absolute lung volume, maximum $₹$ expiratory flow is lower postdive.

The functional significance of changes in pulmon- $\vec{D}$ ary function after deep dives is indicated by the striking reduction of $\mathrm{Tl}_{\mathrm{co}}$. The transfer of $\mathrm{CO}$ from $\mathrm{N}$ alveoli to haemoglobin depends on the area available o for diffusion, the condition of the membrane over $N$ which diffusion takes place, the capillary area with its blood volume, and haemoglobin concentration. Theo measurement of static lung volumes as well as $V_{A O}$ show that the lung volume and thereby alveolar area available for diffusion is almost unchanged. The $\stackrel{\infty}{+}$ haemoglobin concentration has been corrected for 0 and does not explain the difference between predive ${ }^{\circ}$ and postdive results. The explanation is then reduced $\overparen{\odot}$ to an increased thickness of the diffusive membrane $\mathbb{Q}$ or a reduced capillary area available for diffusion.

Reductions in $\mathrm{Tl}_{\mathrm{co}}$ have been shown after exposure to both normobaric and hyperbarico oxygen $^{672324}$ and the time for complete recovery may 
be several weeks. In the study by Puy et al the $\mathrm{Tl}_{\mathrm{co}}$ was partitioned into the membrane and blood components, and the main reduction in $\mathrm{Tl}_{\mathrm{CO}}$ was in the blood component, indicating changes in the pulmonary capillary bed. ${ }^{24} \mathrm{Hyacinthe} e \mathrm{e}$ al have shown a $13 \%$ reduction of $\mathrm{Tl}_{\infty}$ after a decompression from 3.1 $\mathrm{MPa}$ at a partial pressure of oxygen of up to $80 \mathrm{kPa}^{7}$ This is definitely a toxic oxygen concentration. The $\mathrm{Tl}_{\mathrm{CO}}$ was still reduced at two weeks after this dive. In the study by Cotes et al after a dive to $3.1 \mathrm{MPa}$, a reduction in $\mathrm{Tl}_{\mathrm{CO}}$ of $9.6 \%$ was shown and the recovery was complete at four weeks postdive. ${ }^{6}$ Our data indicates a recovery time of more than five weeks depending on the initial reduction. $\mathrm{Tl}_{\mathrm{Co}}$ does not significantly correlate with duration of the dives, but seems in some way to be related to the change in TLC as reflected by the negative correlation between change in $\mathrm{Tl}_{\mathrm{CO}}$ and TLC.

Other significant correlations between changes in lung function parameters and characteristics of the hyperbaric exposure or the divers themselves were not found, such as age, depth, rate of decompression, or partial pressure of oxygen. The individual response to the environmental challenges differ considerably and with so many aetiologic factors acting simultaneously makes it difficult to draw conclusions. The range of variation for oxygen concentrations and rates of decompression in these dives are also small. Systematic studies of routine operational saturation diving to less than $2 \mathrm{MPa}$ should be carried out, making the correlations over a wider range for the independent variables.

It may be concluded that significant pulmonary changes after deep saturation diving are induced by the dive and that the recovery may take several weeks. The findings of this study support the findings in cross sectional studies which indicate the development of airflow limitation in professional divers. So long as effects on long term health are mostly unknown, efforts should be taken to assure that a complete recovery has taken place before other dives are done, not only deep dives but also routine diving. The $\mathrm{Tl}_{\mathrm{co}}$ test and static lung volumes should be considered in the follow up examinations of divers.

This work was supported by Norsk Hydro, Statoil, and the Royal Norwegian Council for Scientific and Industrial Research (NTNF). K Segadal was supported by grants from the Norwegian Research Council for Science and the Humanities (NAVF) from 1986 to 1988 and the Hyperbaric Medical Research Programme (grant No 13.91.99-118).
1 Maio DA, Fahri LE. Effect of gas density on mechanics of breathing. J Appl Physiol 1967;23:687-93.

2 Hlastala MP, Robertson HT, Ross BK. Gas exchange abnormalities produced by venous gas emboli. Respir Physiol 1979;36:1-17.

3 Neuman TS, Spragg RG, Wagner PD, Moser KM. Cardiopulmonary consequences of decompression stress. Respir Physiol 1980;41:143-53.

4 Smith RM, Hong SK, Dressendorfer RH, Dwyer HJ, Hayashi E, Yelverton C. Hana Kai II: a 17-day dry saturation dive at 18.6 ATA. Cardiopulmonary functions. Undersea Biomed Res 1977;4:267-81.

5 Yamasaki M, Taya Y, Fujiie K, Seki K, Sasaki T, Nakayama H. Effect of a simulated saturation dive to 31 ATA on pulmonary function. Ann Physiol Anthropol 1986;5:191-6.

6 Cotes JE, Davey IS, Reed JW, Rooks M. Respiratory effects of a single saturation dive to $300 \mathrm{~m}$. Br J Ind Med 1987;44:76-82.

7 Hyacinthe R, Giry P, Brousolle B. Development of alterations in pulmonary diffusing capacity after a deep saturation dive with high oxygen level during decompression. In: Bachrach AJ, Matzen MM, eds. Underwater physiology VII. Proceedings of seventh symposium on underwater physiology. Bethesda: Undersea Medical Society, 1979:75-83.

8 Spencer MP, Clark HF. Precordial monitoring of pulmonary gas embolism and decompression sickness. Aerospace Med 1972;43:762-7.

9 Watt S. Effect of commercial diving on ventilatory function. $\mathrm{Br} \mathrm{J}$ Ind Med 1985;42:59-62.

10 Davey IS, Cotes JE, Reed JW. Relationship of ventilatory capacity to hyperbaric exposure in divers. J Appl Physiol 1984;56:1655-8.

11 Crosbie WA, Reed JW, Clarke MC. Functional characteristics of the large lungs found in commercial divers. J Appl Physio $1979 ; 46: 639-45$.

12 Quanjer $\mathrm{PhH}$, ed. Standardized lung function testing. Bull Europ Physiopathol Respir 1983;19(suppl 5).

13 Rosner B. Fundamentals of biostatistics. Boston: Duxbury Press, 1982.

14 Leith DE, Bradley $M$. Ventilatory muscle strength and endurance training. J Appl Physiol 1976;41:508-16.

15 Clanton TL, Dixon GF, Drake J, Gadek JE. Effects of swim training on lung volumes and inspiratory muscle conditioning. J Appl Physiol 1987;62:39-46.

16 Jones R, Zapol WM, Reid L. Pulmonary artery remodelling and pulmonary hypertension after exposure to hyperoxia for 7 days. Am J Pathol 1984;117:273-80.

17 Hall JE, Hofman WF, Ehrhart IC. Venous occlusion pressure and vascular permeability in the dog lung after air embolization. J Appl Physiol 1988;65:34-40.

18 Ohkuda K, Nakhara K, Binder A, Staub NC. Venous air emboli in sheep: reversible increase in lung microvascular permeability. J Appl Physiol 1981;49:887-94.

19 Harabin AL, Homer LD, Weathersby PK, Flynn ET. An analysis of decrements in vital capacity as an index of pulmonary oxygen toxicity. $J$ Appl Physiol 1987;63:1130-5.

20 Riley DJ, Cramer MJ, Kerr JS, Chae CU, Yu SY, Berg RA. Damage and repair of lung connective tissue in rats exposed to toxic levels of oxygen. Am Rev Respir Dis 1987;135:441-7.

21 Flick MR, Perel A, Staub NC. Leucocytes are required for increased lung microvascular permeability after microembolization in sheep. Circ Res 1981;48:344-51.

22 Flick MR, Milligan SA, Hoeffel JM, Goldstein IM. Catalase prevents increased lung microvascular permeability during air emboli in unanesthetized sheep. J Appl Physiol 1988;64: 929-35.

23 Caldwell PRB, Lee WL Jr, Schildkraut HS, Archibald ER. Changes in lung volume, diffusing capacity and blood gases in men breathing oxygen. J Appl Physiol 1966;21:1477-83.

24 Puy RJM, Hyde RW, Fisher AB, Clark JM, Dickson J, Lambertsen $\mathrm{CJ}$. Alterations in the pulmonary capillary bed during early $\mathrm{O}_{2}$ toxicity in man. J Appl Physiol 1968;24: $537-43$.

Accepted 5 June 1989 